\title{
Analisis Pengelolaan Air Bekas Wudhu' Jamaah Mesjid Jamik Lambaro Kabupaten Aceh Besar
}

\author{
Bahagia $^{1^{*}}$, Muhammad Nizar ${ }^{2}$ \\ 1,2 Staf Pengajar Program Studi Teknik Lingkungan Fakultas Teknik, \\ Universitas Serambi Mekkah, Batoh, Banda Aceh \\ *Koresponden email: bahagia.ishak@gmail.com
}

\begin{abstract}
Used water has the potential to be processed and recycled based on its continuous volume and quality that allows processing in place. The need for the importance of water is not balanced with consciousness to conserve water, so that many sources of water are polluted by human actions themselves. The purpose of this study is to determine the level of waste water usage of ablution activities, to know the performance of water treatment using ablution water through a combination of slow sand filter; and analyze the content of BOD5, E.colli / total coliform, $\mathrm{pH}$ and ablution water temperature. This research took samples at Jamik Lambaro Mosque, Regency of Aceh Besar, then tested in Environmental Engineering Laboratory of Environment of Serambi Mekkah University. The results showed that the use of ablution water increased at the time of five daily prayers, especially on Friday reached 1,579 people with the use of water ablution reached 4747 liters. Currently, there is no water treatment for the former Mosque of Jami' Lambaro Mosque, the waste water is dumped into the mosque's drainage ditch. Based on ablution water treatment with sand combination has decrease efficiency of BOD5 equal to $95 \%$. The results of laboratory tests showed that the BOD5 content of $17 \mathrm{mg} / 1$, its value under the standard quality of $50 \mathrm{mg} / 1$. E.colli / total coliform that is 0 from 100 $\mathrm{ml}$ that meets the quality standard in accordance with Kep.Men LH RI No. 5 year 2014. The result of temperature / temperature analyst is $28,9 \mathrm{oC}$ and $\mathrm{pH}$ is 7,34 .
\end{abstract}

Keywords: Water used, processed, water ablution, sand filter, waste water

Abstrak: Air bekas memiliki potensi untuk diolah dan didaur ulang berdasarkan volumenya yang kontinyu dan kualitasnya yang memungkinkan diolah di tempat. Kebutuhan akan pentingnya air tidak diimbangi dengan kesadaran untuk melestarikan air, sehingga banyak sumber air yang tercemar oleh perbuatan manusia itu sendiri. Tujuan penelitian ini untuk mengetahui tingkat pemakaian air bekas dari aktivitas wudhu, mengetahui kinerja pengolahan air bekas air wudhu dengan menggunakan kombinasi saringan pasir lambat; dan menganalisa kandungan BOD5, E.colli/total coliform, $\mathrm{pH}$ dan suhu air bekas wudhu. Penelitian ini mengambil sampel di Mesjid Jamik Lambaro Kabupaten Aceh Besar, selanjutnya dilakukan uji di Laboratorium Lingkungan Teknik Lingkungan Universitas Serambi Mekkah. Hasil penelitian menunjukkan bahwa penggunaan air wudhu meningkat pada waktu shalat lima waktu, terutama pada hari Jumat mencapai 1.579 orang dengan penggunaan air wudhu mencapai 4.747 liter. Saat ini belum dilakukan pengolahan air bekas wudhu Mesjid Jami' Lambaro, air limbahnya dibuang ke dalam saluran pembuangan masjid. Berdasarkan pengolahan air wudhu dengan kombinasi pasir memiliki penurunan efesiensi BOD5 sebesar $95 \%$. Hasil pengujian laboratorium menunjukan bahwa kandungan BOD5 yaitu $17 \mathrm{mg} / \mathrm{l}$, nilainya dibawah baku mutu yaitu $50 \mathrm{mg} / \mathrm{l}$. E.colli/total coliform yaitu 0 dari $100 \mathrm{ml}$ yang memenuhi baku mutu sesuai dengan Kep.Men LH RI No 5 tahun 2014. Hasil analis suhu/temperatur yaitu $28,9{ }^{\circ} \mathrm{C}$ dan $\mathrm{pH}$ yaitu 7,34.

Kata Kunci : Air bekas, diolah, air wudhu, saringan pasir, air buangan 


\section{Pendahuluan}

Aceh merupakan salah satu daerah yang mayoritas penduduknya menganut agama Islam. Salah satu kegiatan mensucikan diri pada agama Islam yaitu berwudhu. Wudhu merupakan suatu kegiatan mensucikan diri dengan membasuh bagian-bagian tubuh menggunakan air. Wudhu wajib dilakukan sebelum beribadah (shalat). Shalat dilakukan sehari semalam 5 (lima) waktu. Kaum muslimin melaksanakan shalat berjamaah di Mesjid. Apalagi pada bulan ramadhan, banyak kaum muslim yang melakukan shalat wajib dan shalat sunnah di mesjid, oleh karena itu penggunaan air untuk berwudhu sebelum shalat juga semakin banyak.

Penggunaan air pada saat melakukan wudhu hanya untuk membasuh beberapa bagian tubuh sehingga banyak air yang terbuang saat wudhu. Pada kondisi saat ini air bekas wudhu dibuang secara langsung tanpa ada pemanfaatan. Air yang masih dalam kondisi bersih bekas air wudhu di buang begitu saja menuju selokan. Banyaknya jumlah air bersih sisa tersebut seharusnya dapat dimanfaatkan untuk keperluan yang lain, sehingga air bekas air wudhu tidak terbuang sia-sia.

Air bekas wudhu termasuk air limbah grey water yang dapat di daur ulang, dimana hasilnya dapat dimanfaatkan untuk air reklamasi seperti untuk air lanskap yakni untuk menyiram tanaman, air kolam ikan, mengepel lantai atau membersihkan kendaraan. Air bekas wudhu dari Mesjid Jamik Lambaro Kabupaten Aceh Besar belum dimanfaatkan. Saat ini tidak dilakukan pengelolaan air bekas wudhu Masjid Jamik Lambaro disebabkan oleh kurangnya dimanfaatkan air bekas tersebut. Oleh sebab itu perlu dilakukan kajian kualitas dari air bekas wudhu dengan melakukan uji kandungan BOD5, E.colli/total coliform, $\mathrm{pH}$ dan suhu air bekas wudhu tersebut.

Penelitian ini bertujuan untuk mengetahui tingkat pemakaian air bekas dari aktivitas wudhu, mengetahui kinerja pengolahan air bekas air wudhu dengan menggunakan kombinasi saringan pasir lambat; dan menganalisa kandungan BOD5, E.colli/ total coliform, $\mathrm{pH}$ dan suhu air bekas wudhu.

\section{Tinjauan Pustaka}

Air bekas yang tidak dapat dipergunakan lagi untuk tujuan semula, baik yang mengandung kotoran manusia (tinja) atau dari aktifitas dapur, kamar mandi dan cuci, dimana kuantitasnya antara 50-70\% dari rata-rata pemakaian air bersih (Kodoatie, 2003). Air limbah adalah air buangan yang berasal dari rumah tangga termasuk tinja manusia dan lingkungan permukiman (PP No.16/2005 tentang Pengembangan SPAM). Air limbah domestik adalah air limbah yang berasal dari usaha dan atau kegiatan permukiman (real estate), rumah makan (restauran), perkantoran, perniagaan, apartemen dan asrama. Air bekas atau greywater adalah semua air limbah dari rumah atau bangunan, selain air limbah yang berasal dari toilet Air bekas memiliki potensi untuk diolah dan didaur ulang berdasarkan volumenya yang kontinyu dan kualitasnya yang memungkinkan diolah setempat. Resiko dari pemanfaatan air daur ulang adalah adanya bakteri patogen yang dapat menginfeksi manusia.

Menurut Kodoatie (2003) air bekas, yang termasuk air ini adalah air limbah, air kotor, air buangan dari dapur, air dari kamar mandi, dan air sebagai sisa proses perusahaan atau industri. Produksi air bekas, jumlah dan komposisinya dipengaruhi oleh faktor kepadatan penduduk, urbanisasi, industri, teknologi, dan sikap anggota masyarakat. Meningkatnya penggunaan air di satu pihak dan berkurangnya sumber air di lain pihak menambah peliknya masalah air bekas karena manusia terpaksa menggunakan kembali air bekas itu.

\section{Saringan Pasir}

Dalam penelitian Agunwamba, J. C. (2012) menyarankan air bekas lebih sesuai dimanfaatkan untuk air irigasi, baik untuk pertanian, maupun air untuk menyiram tanaman kebun. Saringan pasir merupakan teknologi sederhana yang dapat digunakan untuk mengolah air bekas (greywater) (Pidou et all, 2007). Faktor yang mempengaruhi efisensi saringan pasir adalah ukuran, jenis media filter serta ketebalan media saringan pasir (Handayani, Dwi Siwi, 2013).

\section{Biological Oxygen Demand (BOD5)}

Biological Oxygen Demand (BOD) adalah suatu analisis empiris yang mencoba mendekati secara global proses-proses mikrobiologis yang 


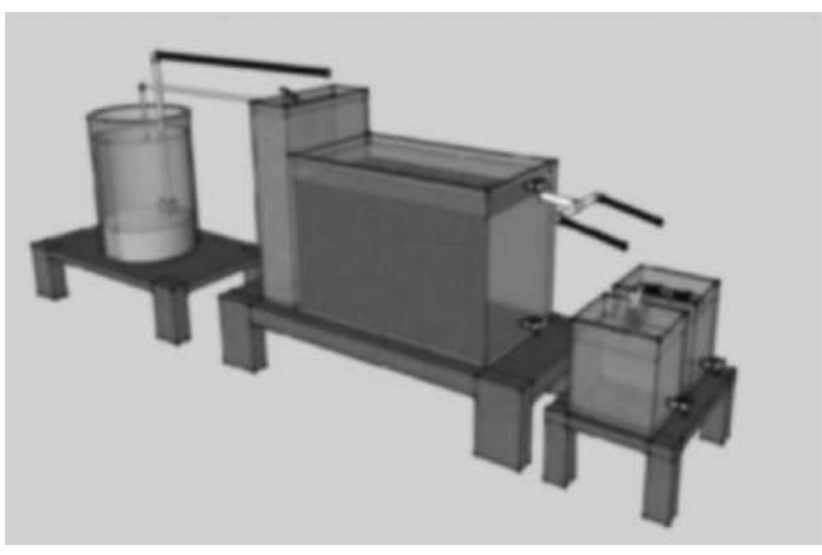

Gambar 1.Sketsa pasir lambar penelitian

Ket : A. Bak Penampung Air Bekas ; B. Reaktor Saringan pasir ; C. Reaktor Lahan Basah Buatan

benar-benar terjadi di dalam air. Pengukuran BOD dilakukan selama 5 hari karena selama 5 hari jumlah senyawa organik yang diuraikan sudah mencapai $70 \%$. BOD merupakan analisis empiris yang mencoba mendekati secara global proses-proses mikrobiologi yang terjadi di dalam air (Alaerts \& Santika, 1997).

\section{Escherichia Coli}

Escherichia coli merupakan sekelompok bakteri yang biasanya ditemukan dalam makanan dan air. Kebanyakan dari bakteri ini tidak berbahaya, tetapi beberapa jenis dapat menyebabkan penyakit. Penyakit akibat $E$.

Tabel 1. Data jamaah Masjid Jami’ Lambaro Aceh Besar

\begin{tabular}{lcccccc}
\hline Hari & $\begin{array}{c}\text { Subuh } \\
(\text { Org })\end{array}$ & $\begin{array}{c}\text { Zhuhur } \\
(\text { Org })\end{array}$ & $\begin{array}{c}\text { Ashar } \\
(\text { Org })\end{array}$ & $\begin{array}{c}\text { Mag- } \\
\text { hrib }\end{array}$ & Isya & Jumlah \\
\hline Senin & 88 & 266 & 256 & 228 & 123 & 961 \\
Selasa & 95 & 287 & 278 & 223 & 115 & 998 \\
Rabu & 92 & 268 & 231 & 212 & 119 & 922 \\
Kamis & 86 & 295 & 245 & 225 & 121 & 972 \\
Juma't & 95 & 918 & 240 & 208 & 118 & 1.579 \\
Sabtu & 90 & 285 & 238 & 217 & 110 & 940 \\
Minggu & 96 & 275 & 241 & 230 & 125 & 967 \\
\hline \multirow{2}{*}{$\begin{array}{c}\text { Rata- } \\
\text { Rata }\end{array}$} & 92 & 371 & 247 & 220 & 119 & \\
\hline & & & & & \\
\hline
\end{tabular}

Sumber : Data penelitian, Juli 2017 coli timbul saat bakteri ini melepaskan racun membuat orang sakit. Racun E. coli paling sering menyebabkan masalah perut dan usus, seperti diare dan muntah (Pelczar dan Chan, 2008).

\section{Derajat keasaman (pH)}

Derajat keasaman $(\mathrm{pH})$ merupakan gambaran jumlah atau aktivitas ion hidrogen dalam perairan. Secara umum nilai $\mathrm{pH}$ menggambarkan seberapa besar tingkat keasaman atau kebasaan suatu perairan. Perairan dengan nilai $\mathrm{pH}=7$ adalah netral, $\mathrm{pH}<7$ dikatakan kondisi perairan bersifat asam, sedangkan $\mathrm{pH}>7$ dikatakan kondisi perairan bersifat basa. Adanya garam dalam bentuk ion $\mathrm{CO} 3{ }^{++}$karbonat, bikarbonat dan hidroksida akan menaikkan kebasaan air, sementara adanya asam-asam mineral bebas dan asam karbonat menaikkan keasaman suatu perairan (Mahida, 1993).

\section{Suhu}

Pembuangan air yang bersuhu tinggi dalam jumlah banyak dapat menaikkan suhu perairan penerima beberapa derajat di atas suhu normal. Kenaikkan itu akan mempengaruhi organismeorganisme penghuni perairan terutama ikan, baik secara langsung maupun tidak langsung (Mahida, 1993).

\section{Metode Penelitian}

Metode yang digunakan dalam penulisan ini adalah metode kuantitatif yang didukung dengan analisis kualitatif. Analisis kuantitatif dilakukan untuk mengukur tingkat pemakaian air bekas dari aktivitas wudhu dengan menggunakan kombinasi saringan pasir lambat dan menganalisa kandungan air limbah dari aktivitas wudhu di Mesjid Jamik Lambaro Kabupaten Aceh Besar secara detail.

Air bekas wudhu Masjid Jamik Lambaro diolah dengan skala laboratorium di Laboratorium Lingkungan, Teknik Lingkungan Universitas Serambi Mekkah. Waktu pelaksanaan penelitian April sampai Desember 2017.

Pengolahan air bekas dilakukan menggunakan saringan pasir. Reaktor penelitian terbuat dari kaca yang transparan dengan tujuan untuk memantau proses yang terjadi. Ukuran reaktor saringan pasir adalah $60 \mathrm{~cm}$ x $40 \mathrm{~cm}$ x $30 \mathrm{~cm}$ yang terbuat dari kaca yang mempunyai tebal $8 \mathrm{~mm}$. Reaktor 
saringan pasir berisi media pasir dengan tebal 10 $\mathrm{cm}$ dan diameter ukuran pasir 0,15-0,35 $\mathrm{cm}$.

Air bekas ditampung dalam wadah, untuk dialirkan secara intermitten menuju saringan pasir. Pengamatan dilakukan hingga terjadi penurunan parameter air bekas yang berarti (signifikan). Parameter yang diukur adalah BOD5, E. Coli, pH, dan Suhu. Sketsa pasir lambat diperlihatkan pada Gambar 1 berikut.

\section{Teknik Analisa Data}

Analisis yang digunakan untuk mengetahui tingkat tingkat pemakaian air bekas dari aktivitas wudhu, menganalisis kinerja pengolahan air bekas air wudhu' dengan menggunakan saringan pasir lambat dan menganalisa kandungan BOD5, E.colli, $\mathrm{pH}$ dan suhu air bekas wudhu di Mesjid Jamik Lambaro Kabupaten Aceh Besar, yaitu analisis deskriptif kuantitatif. Pengambilan data dilakukan berdasarkan uji laboratorium yang hasilnya diolah dan dilakukan klasifikasi dengan menggunakan variabel pengolahan air bekas air wudhu' di Mesjid Jamik Lambaro Kabupaten Aceh Besar. Analisis deskriptif dilakukan untuk mengetahui tingkat pengolahan air bekas air wudhu' di Mesjid Jamik Lambaro Kabupaten Aceh Besar. Parameter yang diukur adalah BOD5, E.coli, $\mathrm{pH}$ dan suhu.

\section{Hasil dan Pembahasan}

Tingkat pemakaian air bekas dari aktivitas

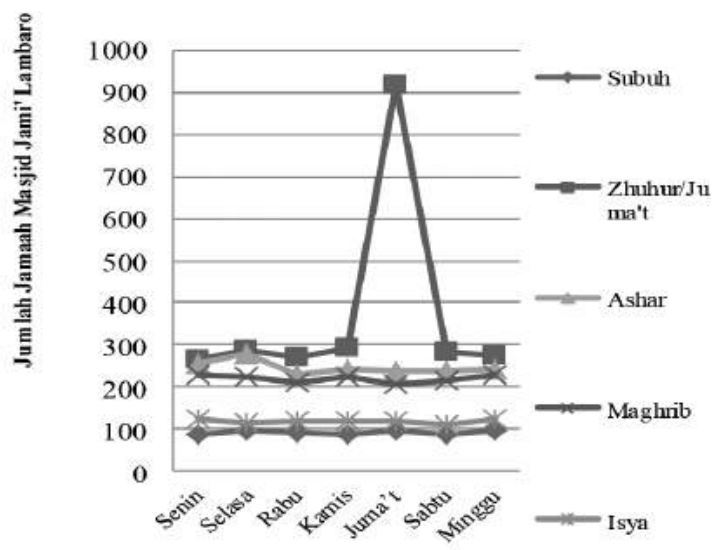

Gambar 2. Jumlah jamaah masjid Jami’ Lambaro pada shalat lima waktu selama satu minggu wudhu meningkat pada waktu shalat 5 waktu dan shalat juma't atau shalat sunnah lainnya. Air bekas wudhu menjadi limbah cair yang tidak dimanfaatkan kembali oleh pengurus Masjid Jami' Lambaro Aceh Besar. Jumlah pemakaian air wudhu di masjid Jami' Lambaro meningkat yang disertai dengan meningkatnya jamaah terdiri dari jamaah laki-laki dan perempuan, juga ada jamaah anak-anak yang ikut shalat di masjid tersebut. Jumlah jamaah masjid Jamik Lambaro yang melaksanakan shalat lima waktu dalam seminggu diperlihatkan dalam Gambar 2.

Gambar 1 menunjukkan bahwa jumlah jamaah masjid Jami' Lambaro meningkat pada saat hari jumat mencapai 1.579 orang.

Selanjutnya jumlah jamaah pengguna air wudhu dalam seminggu diperlihatkan pada Gambar 3.

Gambar 3 menunjukkan bahwa jumlah jamaah Masjid Jami' Lambaro yang melaksanakan shalat lima waktu meningkat jumlah jamaahnya pada hari Jumat.

\section{Jumlah penggunaan air wudhu}

Jumlah penggunaan air wudhu berdasarkan rata-rata jumlah air yang digunakan dalam sekali berwudhu adalah sebesar 3 liter/orang. Jumlah penggunaan air wudhu oleh jamaah Mesjid Jami' Lambaro Aceh Besar diperlihatkan pada Tabel 2.

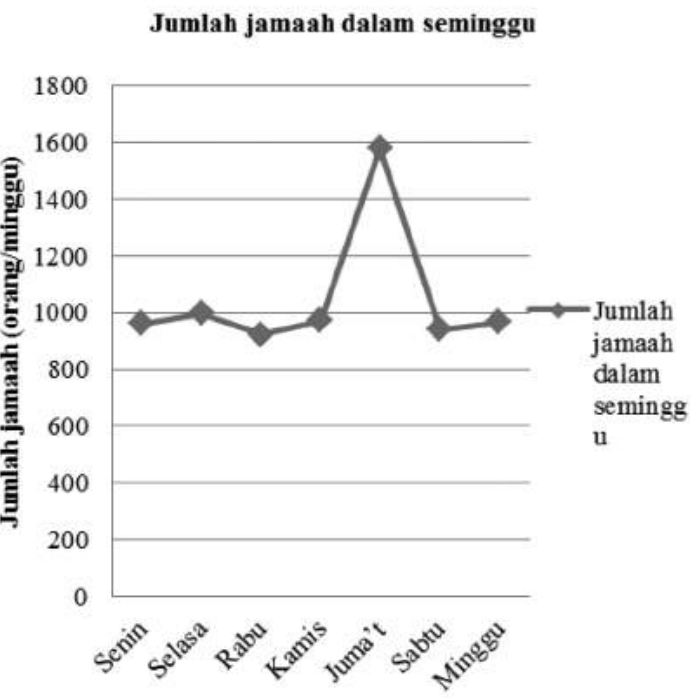

Gambar 3. Jumlah jamaah masjid Jami’ Lambaro selama satu minggu 
Tabel 2. Jumlah penggunaan air wudhu dalam liter selama seminggu

\begin{tabular}{lcccccc}
\hline & Subuh & Zhuhur & Ashar & Maghrib & Isya & $\begin{array}{c}\text { Jumlah } \\
\text { (Liter) }\end{array}$ \\
\hline Senin & 264 & 798 & 768 & 684 & 369 & 2.883 \\
Selasa & 285 & 861 & 834 & 669 & 345 & 2.994 \\
Rabu & 276 & 804 & 693 & 636 & 357 & 2.766 \\
Kamis & 258 & 885 & 735 & 675 & 363 & 2.916 \\
Juma't & 285 & 2,754 & 720 & 624 & 354 & 4.737 \\
Sabtu & 270 & 855 & 714 & 651 & 330 & 2.820 \\
Minggu & 288 & 825 & 723 & 690 & 375 & 2.901 \\
\hline Rata- & 275 & 826 & 741 & 661 & 356 & \\
\hline Rata & & & & & & \\
\hline
\end{tabular}

Tabel 2 menunjukkan jumlah pemakaian air wudhu selama satu minggu sebesar 22.017 liter. Selanjutnya penggunaan air wudhu oleh jamaah untuk shalat 5 waktu selama satu minggu diperlihatkan pada Gambar 4.

Gambar 4 menunjukkan bahwa jumlah penggunaan air wudhu jamaah Masjid Jami' Lambaro meningkat jumlah penggunaannya pada hari Jumat dan pemakaian rendah pada hari

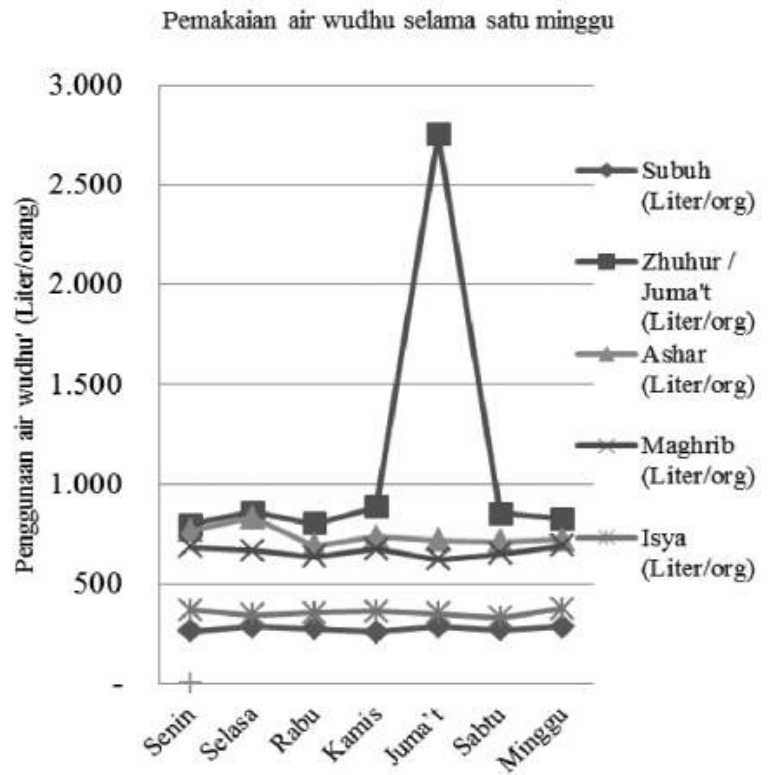

Gambar 4. Jumlah penggunaan air wudhu shalat lima waktu selama satu minggu

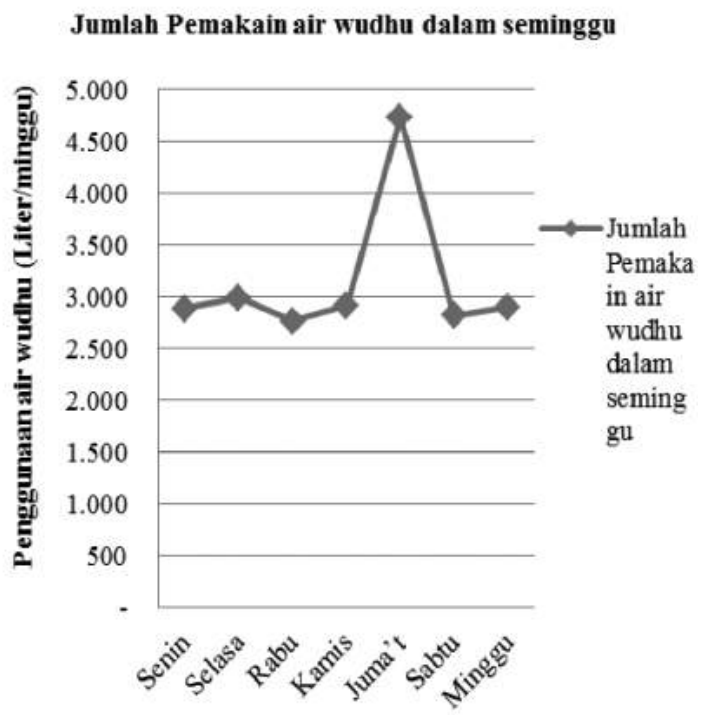

Gambar 5 Jumlah penggunaan air wudhu selama satu minggu

Rabu yaitu 2.766 liter. Dalam berwudhu sering kali jamaah menggunakan air secara berlebihan, sehingga menghasilkan limbah air wudhu yang terbuang sia-sia. Jumlah konsumsi air bersih yang digunakan untuk keperluan wudhu adalah sebesar $14,6 \%$.

Jumlah Penggunaan air wudhu selama satu minggu diperlihatkan pada Gambar 5.

Gambar 5 menunjukkan bahwa tingkat pemakaian air wudhu meningkat dalam waktu seminggu. Hari Jum'at merupakan hari yang banyak pemakaian air wudhu sebesar 4.737 liter.

\section{Analisa kandungan BOD5}

Parameter BOD5 adalah parameter yang menunjukkan beban pencemar organik dalam air. Semakin besar nilai BOD5, semakin tinggi tingkat pencemaran air. Hasil pengujian laboratorium BOD5 air bekas wudhu menunjukan bahwa kandungan BOD5 sebesar $17 \mathrm{mg} / \mathrm{l}$, nilainya dibawah baku mutu yaitu $50 \mathrm{mg} / \mathrm{l}$. Berdasarkan pengamatan pengolahan air wudhu dengan kombinasi pasir memiliki penurunan efesiensi BOD5 sebesar 95 $\%$. Hal ini menunjukkan bahwa air limbah dari bekas air wudhu tidak tercemar sehingga bisa dimanfaatkan kembali untuk menyiram tanaman, air kolam ikan, mengepel lantai atau membersihkan kendaraan. Saat ini belum dilakukan pengolahan air bekas wudhu, air limbahnya dibuang ke dalam saluran pembuangan masjid. 


\section{Analisa E.colli}

E.colli/total coliform dari air limbah bekas air wudhu menunjukkan nilainya 0 dari $100 \mathrm{ml}$, hal ini memenuhi baku mutu Kep.Men LH RI No 5 tahun 2014. Nilai e.colli/total coliform dari air bekas wudhu telah memenuhi baku mutu air minum sehingga air limbah bekas air wudhu bisa dimanfaatkan kembali.

\section{Analisa pH dan suhu air bekas wudhu}

Hasil uji suhu/temperatur air limbah bekas air wudhu menunjukkan nilainya yaitu $28,9{ }^{\circ} \mathrm{C}$ dan pH yaitu 7,34.

\section{Kesimpulan}

1. Volume air bekas air wudhu Masjid Jami' Lambaro mengikuti jumlah jamaah, terutama hari jumat mencapai 1.579 orang jamaah dan penggunaan air wudhu meningkat sampai 4.737 liter.

2. Berdasarkan pengamatan pengolahan air wudhu dengan kombinasi pasir memiliki penurunan efesiensi BOD5 sebesar $95 \%$.

3. Hasil pengujian laboratorium BOD5 air bekas wudhu menunjukan bahwa kandungan BOD5 sebesar $17 \mathrm{mg} / \mathrm{l}$, nilainya dibawah baku mutu yaitu $50 \mathrm{mg} / 1$. E.colli/total coliform menunjukkan nilainya 0 dari $100 \mathrm{ml}$. Hasil uji suhu/temperatur menunjukkan nilainya yaitu $28,9{ }^{\circ} \mathrm{C}$ dan $\mathrm{pH}$ yaitu 7,34

\section{Daftar Pustaka}

Alaerts, G \& Santika, S.S. 1984. Metoda Penelitian Air, Penerbit Usaha, Surabaya.

Agunwamba, J. C. (2012). Grey Water Reuse for Irrigation. International Journal of Applied, 2(8). http://www.ijastnet.com/journals/ Vol_2_No_8_October_2012/12.pdf

Mahida, U.N, 1993, Pencemaran Air dan Pemanfaatan Limbah Industri, PT Raja Gravindo Persada, Jakarta.

Dwi Siwi Handayani, 2013, Kajian pustaka potensi pemanfaatan greywater sebagai air siram we dan air siram tanaman di rumah tangga, Jurnal Presipitasi, Vol. 10 No.1 Maret 2013, ISSN 1907- 187X

Pidou, M., Memon, F. A., Stephenson, T., Jefferson, B., \& Jeffrey, P. (2007). Greywater recycling: treatment options and applications. Proceedings of the ICEEngineering Sustainability, 160(3), 119-131. http://web.stanford.edu/group/narratives/ classes/0809/CEE215/Projects/greendorm/ water/GraywaterCD/graywater08/nsu $\% 252$ E2007\%252E160\%252E3\%252E119.pdf

Pelczar., Michael J. dan E. C. S. Chan, 2008. Dasar-dasar Mikroorganisme. Universitas Indonesia Press. Jakarta.

PP No.16 Tahun 2005 tentang Pengembangan SPAM.

Kodoatie, R.J. (2003). Manajemen dan Rekayasa Infrastruktur. Yogyakarta: Pustaka Pelajar. 